\title{
Constructing a healthy, knowledgeable and well- educated citizen: Motivational interviews and physical activity on prescription
}

Erika Åkerblom and Andreas Fejes

The self-archived version of this journal article is available at Linköping University Electronic Press:

http:// urn.kb.se/ resolve?urn=urn:nbn:se:liu:diva-138394

N.B.: When citing this work, cite the original publication.

This is an electronic version of an article published in:

Akerblom, E., Fejes, A., (2017), Constructing a healthy, knowledgeable and well-educated citizen: Motivational interviews and physical activity on prescription, Studies in Continuing Education https:// dx.doi.org/ 10.1080/0158037X.2017.1334641

Original publication available at:

https:// dx.doi.org/ 10.1080/0158037X.2017.1334641

Copyright: Taylor \& Francis (Routledge): SSH Titles

http:// www.routledge.com/ 


\title{
Constructing a healthy, knowledgeable and well-educated citizen: Motivational interviews and physical activity on prescription
}

\author{
Erika Åkerblom \& Andreas Fejes \\ Published in Studies in Continuing Education
}

\begin{abstract}
In recent decades education has been suggested as an important solution to current problems of the population's health. A high level of education in general is construed as essential for the nation's well-being and competitiveness. In this article we problematise the ways in which discourses on education, learning and health have become interlinked. Drawing on a poststructural theorisation inspired by Michel Foucault, we analyse Swedish policy documents on education and public health and direct our attention to how the healthy citizen is shaped and fostered. We illustrate how the healthy citizen emerges in opposition to the non-healthy, nondesirable and abnormal citizen. Citizens are made responsible for identifying their deficits and suggesting solutions. Governing techniques, such as motivational interviews and physical activity on prescription, operates in order to shape such citizens. Through these techniques, a confessional relation emerges, where citizens are invited to disclose their deficits and problems and in so doing shape themselves in a desired way.
\end{abstract}

Keywords: adult education, health, motivational interviews, physical activity on prescription, governmentality, Foucault

\section{Introduction}

In the last century education has been regarded as an important tool for the development of society. Such ambition has been accompanied by increased levels of education in the population as a whole. Zooming in on Sweden, a recent example of the role of education is promoted as essential for the creation of a knowledge society. This is exemplified in a government paper in the following way:

Sweden's position as a knowledge nation must be strengthened. The challenge is to build a
learning community with extensive investments in education at all levels, which connect to the
classical task of welfare policies, to drive change and modernization of society. In the
emerging new society education is a crucial part for a person's future life, opportunities in life
and professional life. Therefore it is important that education is made available to everyone,
not just for the few. (Motion 2010/11:Ub445, 1)

Here, arguments for more education connect to the idea that Sweden's position vis-à-vis other countries needs to be strengthened. Key words like 'modernisation', 'welfare policies' and 'opportunities' for 'everyone' illuminate the democratic function of education (see e.g. Nicoll et al. 2013). Arguments like this are not new. Rather, the ideas that have emerged in the last century have been linked up in different ways (see e.g. Fejes 2006).

Ideas about democracy, modernisation and welfare have been and still are central in today's discussion about education. What is new is, on the one hand, that policy documents speak about 
learning rather than education as a path in order to meet challenges of the future. On the other hand, health has emerged as a central component in these discussions. For example, in a report from 1998, OECD introduced the idea that health is one important output of increased levels of education among the population. They argue (OECD, 1998, 66) that 'there is clear evidence that better educated people tend to be healthier, even correcting for the health benefits that they enjoy because of their higher income'. Such benefits are in the report related to education in general, but also to learning in a wider sense. Similar ideas have been picked up in Sweden, not the least since the late 1990s. Education was then not only construed as important for individuals' employability or higher pay, but also for less illness and a longer life. As argued in a government paper on higher education from 2001: 'On average, those who have studied at university have for example less risk of unemployment, more years of work, less illness, longer life and higher pay' (Ministry of Education 2001, 19) and as argued in a government paper on lifelong learning, referring to the OECD report from 1998 that 'in a broader perspective [...] beside the economical revenues due to education, there is also a social revenue [...] as education influence factors such as self-esteem, health and participation in society' (Ministry of Education, 1999, 34).

With such a positive aspect of education and learning, different measures have been suggested to increase the health of the population, make health more equitable and increase life expectancy rates. These measures are amongst other things aimed at providing 'people opportunities to increase control over their health and to improve it' (Ministry of Health and Social Affairs 2007, 9). Thus, the conception of education seems to have shifted to one of education AND learning as an important solution to the population's current health problems. This is what Foucault (2007) calls the problematics of governing, where certain futures, challenges and solutions emerge that aim to make citizens change their behaviour in order to participate in the shaping of a successful future. In other words, these ways of speaking and these discourses help to shape subjectivity and, in that sense, become dangerous or problematic and thus need to be further scrutinised (Foucault 1983).

The aim of this article is to problematise the ways in which education, learning and health have become interlinked in current policy making in Sweden. More specifically, the focus is on how the healthy citizen is construed, which characteristics become related to such citizen and what this might mean for the future.

\section{Research on education and health}

Research on the relation between education and health is not new, although it often focuses on how education can contribute to improving the health of the population. This includes studies of measurable health effects, such as life expectancy, physical symptoms like neck or shoulder pain, the mortality rate from cardiovascular diseases (cf. Public Health Agency of Sweden 2016; SCB.se), or research aimed at examining the link between, and effects of, education and the population's well-being (e.g. Groot \& Maassen van den Brink 2007; Hahn \& Truman 2015; Hammond 2002, 2004; Loucks et al. 2011; Mayfield-Johnson et al. 2014; Merriam \& Kee 2014; Zepke 2013) or physical education in schools (e.g. Ericsson \& Karlsson 2014; Hills et al. 2015; Quennerstedt 2006; 2008, Tolgfors \& Öhman 2016). 
However, there are also more critical studies on health, education and learning, to which our study connects up, where the work of Foucault has been a central inspiration (e.g. Berglund 2008; Björklund 2008; Olsson 1997; Popkewitz, Olsson \& Peterson 2006). Here, the focus has, for example, been directed at how public health policies in Sweden have shifted (Olsson, 1997) from a view on public health in terms of the absence of illness, whereas today public health is defined in terms of psychological and emotional well-being and quality of life. Similar arguments are pursued by (Berglund, 2008) who illustrate how policies on lifelong learning in Sweden could be conceptualised as a medical discourse (Berglund 2008). Here, the logic is that those who cannot or do not wish to become lifelong learners are pathologised as being in need of correction. Such corrections are encouraged and mobilised by experts operating as nurses or medical doctors, i.e. the experts aim to correct the illness and instil a will to learn. Learning activities aimed at increased health at the workplace, is yet another practice scrutinized from a more critical perspective, where, e.g. it has been illustrated how discourses on health contributes to shaping the healthy employee where the biomedical and the wellness discourse are the most prominent for constituting the desirable subject (Björklund, 2008).

Our analysis connects up with this latter, Foucault-inspired research on education, learning and health. However, rather than focusing on either education, or (lifelong learning), or the work place, we direct attention to how education, learning and health become interlinked within current discourses in Sweden. Through such discourses a healthy citizen emerges. Thus, the article contributes knowledge that could furnish further critical discussions about the effects of current discourses on education, learning and health in terms of shaping subjectivity.

\section{Theoretical and methodological approach}

In order to analyse how subjectivity is shaped through current discourses on education, learning and health, we draw on a post-structural and discursive theorisation inspired by the work of Michel Foucault (1972, 1980, 2007) and specifically on those education scholars who have developed and mobilised such a perspective (Fejes 2006, 2010; Nicoll et al. 2013; Olson et al. 2014; Simons \& Masschelein 2008). Concepts such as discourse, governmentality and subjectivity are central analytical concepts. In this approach, 'discourse' includes what is said or written, but is actually more than this. A discourse is not just the signs of language, but a system for the formation of a group of statements that is not limited to what is being said (Foucault 1972). In relation to the healthy citizen, discourses are constituted through statements that emerge as possibilities for speech, events and action-taking at a particular time and location. These statements are considered as entities that allow signs to assign specific and repeatable relations to objects, subjects and other statements. These relations have different features; a vital feature being the construction of subjectivity.

Here, subjectivity is not pre-defined and has no essence. Rather, subjectivity emerges through the ways that citizens are described in texts and speech. In other words, this is a decentred notion of subjectivity that is enmeshed in power relations, which makes these relations possible. Through these relations, governing operates, and Foucault (2007) described this as governmentality, thus broadening the taken for granted notion that governing is something that is conducted by the state (see Foucault 2007). Here, 'government' is not only concerned with 
governing through state control, law-making, policy decisions and institutional curriculum practices and so forth, but occurs in and through discourses and practices that inform our everyday actions and are drawn on in our relations to ourselves (Fejes \& Nicoll 2008). Foucault (2007) uses the concept of the 'conduct of conduct' to analyse how people are constituted as governors of others and the self. Governing, then, is the guidance of conduct.

A governmentality analysis directs attention toward the technologies and techniques through which governing operates and reaches its goals (how governing operates), combined with an analysis of which subjects are brought forth through them (the effect of governing). Technologies do not have any essence and are not the direct linear output of a specific will or intention to govern. Instead, they are assemblages of aspirations, beliefs, knowledge and practices of calculations that, for example, aspire to shape specific subjectivities (Rose 1999). Foucault (2003) primarily analyses two types of technologies in his writings: technologies of power and domination and technologies of the self. The former concerns the practices through which the self is objectified and shaped by dividing practices, whilst the latter concerns the ways in which the self constitutes itself as a subject. These technologies seldom function separately. Rather, the encounter between the two is what Foucault calls governmentality.

One central technology of the self mentioned by Foucault (1978) is the confession. Confession is often associated with religious confession, especially in a Catholic context. With the emergence of science in the 1800s confession became scientised to the extent that today confession operates in many different spheres, e.g. in the family, between friends and coworkers etc. (Foucault, 1978; Fejes \& Dahlstedt, 2014). Confession is a ritual of discourse in the sense that someone always incites and invites someone to confess. This could be a friend, a teacher, or even oneself, i.e. as a 'virtual other' (Fejes \& Dahlstedt, 2014). Confessing implies that you already know how you should be and behave, in that the act of confession means telling the truth about who you are and who you should be or become. Accordingly, by confessing we contribute to, and co-create, knowledge about ourselves through verbalisation of our self, and thus participate in governing ourselves in accordance to current norms of good behaviour.

In order to analyse how education, learning and health intersect today in Sweden, we have selected policy texts published in policy locations where these topics are raised. This includes reports written by the Ministry of Education, Ministry of Health and Social Affairs, the Public Health Agency of Sweden, and the National Board of Health and Welfare. Drawing on a governmentality analysis, the following questions guide our analysis (see Fejes 2006; Dean 1999): What is the problematic of governing? What kind of subjectivity is desired? Through what means should such subjectivity be shaped? In order to answer these analytical questions, the focus is on identifying regularities of statements (see e.g. Fejes \& Nicoll 2015; Fejes \& Dahlstedt 2014) in the policy texts. Such regularities make certain ways of understanding the (healthy) citizen possible.

In the following, we first of all describe how healthy citizens are construed through current discourses. Secondly, we zoom in on how normal and deviant citizens emerge as opposites. Thirdly, attention is directed to how the governing techniques of motivational interviews and 
physical activity on prescription are mobilised in order to shape the normal and desirable subjectivity. The article ends with a discussion.

\section{What and who is the problem?}

The current policy texts describe how public health has improved in recent decades, which through discourse is construed as something positive. However, at the same time it is stated that inequalities in health have increased between different population groups.

\footnotetext{
Sweden has for a long time had a very good public health and we can see that over the decades health has improved, in terms of life expectancy and other health indicators. Unfortunately, we also see that inequalities in health between different groups of the population seem to increase rather than decrease, which is our biggest challenge in public health work. (Public Health Agency of Sweden 2015a, v)
}

The main problem construed here is the inequalities in health between different population groups in Sweden and that measures need to be taken to counteract this development. The texts further elaborate on the reasons for this. The main explanation is that health inequalities stem from complex circumstances. However, healthy lifestyle choices and living conditions are argued to be better amongst citizens with higher levels of education than those with lower levels of education (Ministry of Health and Social Affairs 2016).

The problematics of governing emerging is thus not so much about the general health of the population, but more about the lessening of the gap between those with good health (people with higher levels of education) and those with less good health (people with lower levels of education). Talking about people in this way creates a division between the healthy and nonhealthy citizen, where the former is positioned as desirable.

\section{The normal and the deviants}

As indicated above, the texts mainly describe the population as generally healthy, and the ambition is for the entire part of the population to become healthy. Thus, the target of interventions is on a general level the entire population. However, the population is at the same time divided into different groups. All is not all in its strict sense. Certain groups of citizens are highlighted as risks and the target of certain measures and interventions (see e.g. Fejes 2006). These risk groups are attributed as lacking something for example adequate education, which in turn is used to explain poor health. This is further illustrated in the following quotation:

Groups that are less resourceful, such as those with shorter education, lower income, poorer housing and fewer opportunities to influence and participate in society, also have poorer health. (Ministry of Health and Social Affairs 2007, 31)

The population is thus categorised into different groups, each having certain characteristics and shortcomings. Indeed, shortcomings are the starting point and contribute to the construction of risk groups as 'something else'. The constructed risk groups are described as deficient in education, income, housing and influence and as having fewer resources, poorer health, and as a consequence, they are construed as having less ability to cope with life. In this way of 
reasoning, a discourse on lack emerges, and not the least a lack of knowledge, i.e. the unhealthy citizen is not a knowledgeable citizen and does not have the required level of education. Lack of education is also linked to unemployment as a further explanation for poor health among certain parts of the population:

Ill health is higher among the unemployed than among people who have jobs, but the relationship between unemployment and ill health is complex. There is a health selection, where people with any form of ill health find it more difficult to get a job, but unemployment also has direct negative health effects on the individual. (Public Health Agency of Sweden 2014, 78)

The complexity referred to here is about causality. The policy document is saying that poor health may be a cause as well as a consequence of unemployment. Those who are highly educated and have a job are said to have a lower risk of poor health than those with little education and no employment. Besides the construction of a relationship between education, health and unemployment, the unemployed citizen is portrayed as someone who is unable to make the proper health choices (e.g. Public Health Agency of Sweden 2015b; Ministry of Health and Social Affairs 2016). This can be seen in the following two quotations, where, on the one hand, citizens with longer education are construed as people whose behaviour promotes good health, and thus, those with low levels of education emerges as the opposite. On the other hand, education in itself is construed as needed in order to make healthy life choices.

Most behaviour that promotes health is more common among people with longer education (Ministry of Health and Social Affairs 2016, 115).

Education can also provide people with better ability to acquire, interpret and use information about, for example, health and various risks. (Public Health Agency of Sweden 2016)

In other words, the less knowledgeable citizen does not have the necessary knowledge or skills to make good choices about their health (i.e. what to eat, how to exercise etc.), but through education they can learn how to act and understand how to behave in order to become 'normal'.

So far, what we see is the emergence of a desirable and undesirable citizen, where the healthy citizen is defined in the light of what is construed as unhealthy. In the texts healthy citizens are shaped as those who are well educated, have a job, know how to handle risk and can take responsibility. In contrast, unhealthy citizens are portrayed as people who do not have the necessary knowledge to make healthy life choices and therefore cannot be expected to take responsibility for their own health, for which they need support.

\section{Techniques for shaping the healthy citizen}

The logic that is construed is that the unhealthy citizen needs to be supported, guided and helped to make the right choices in order to become healthy. Such a citizen is positioned as not yet fully understanding that good health is an important goal to achieve and that the only way to do this is to have easier access to education. Although such citizens are not portrayed as being completely helpless, they are construed as having little interest in searching for knowledge about how to make the right choices to achieve good health. Thus, the opportunity to acquire knowledge that promotes health must be facilitated. 
The government wants to promote individuals' interests, responsibilities and opportunities to take responsibility for their own health. [...] It is important that individuals themselves are given the opportunity to articulate their problems and be given opportunities to find solutions. It is inner motivation rather than external control that is in focus. [...] efforts aimed at making individuals capable of taking control of their own health and improving it [...] (Ministry of Health and Social Affairs 2007, 10).

The message here is that individuals' own possibilities to be responsible should be encouraged and that they should be given the opportunity to create their own stories about their lack of health and suggest solutions. By increasing the motivation of the target groups for educational interventions the idea is that people will find ways of taking control of their lives and thereby become healthy. Rather than external control, the idea is shaped in terms of internal control. In other words, interventions directed at individuals' inner selves. By encouraging unhealthy citizens to direct their gaze inwards and identify their own deficits, the expected outcome is a citizen who knows how to behave in order to become healthy. A responsible citizen is thus also one who can make autonomous choices, which is further illustrated in the following quotation.

\footnotetext{
An important aim of the government's public health policy is to provide knowledge and insights that enable people to both make autonomous health decisions based on facts, and to develop the skills required for a healthy lifestyle. Major improvements in health can be achieved if the individual is able to take, and takes, a greater responsibility for his or her health. (Ministry of Health and Social Affairs 2007, 7)
}

The above quotation suggests that an autonomous and responsible citizen will emerge with the support of experts who will guide them in their path towards self-knowledge. Such support is illustrated in terms of providing (scientifically based) knowledge, as shown in this quotation:

Health information is a planned activity that helps people to voluntarily implement change in their behaviour. (Ministry of Health and Social Affairs 2007, 13)

However, as indicated, the choice to follow the advice and knowledge acquired is voluntary and therefore up to each individual. Although the process is described as 'voluntary', the expected outcome is a modification of behaviour.

Besides providing knowledge in general terms as suggested here, specific techniques are mobilised that in different ways aim at the client's knowledge of the self. Two of these techniques - motivational interviews and physical activities on prescription - are elaborated on below.

\section{Motivational interviews}

Information as a means of shaping and fostering autonomous and responsible healthy citizens is also combined with specific techniques that work on the inner self of each citizen. One such technique is motivational interviews. Here, the aim is to motivate and increase the capacity of the unhealthy citizen, as illustrated in the following quotation: 
Motivational interviews have in several studies been shown to be an important tool for health care professionals discussing lifestyle and behavioural changes with their patients. Almost all medical procedures involve the patient's participation in one way or another. (Ministry of Health and Social Affairs 2007, 13)

Here, it is suggested that motivational interviews can be mobilised more or less anytime when a doctor or nurse meets a patient. By introducing motivational interviews, an 'equal' relationship is constructed between the health professional and the patient. During these lifestyle conversations, the patient is expected to actively contribute by identifying problems and suggesting solutions. This is exemplified in the guidelines for motivational interviews outlined by the National Board of Health and Welfare (2016), which emphasises the following:

Central principles for motivational interviews are:

- Through the means of empathetic and reflective listening, try to understand.

- Not argue with clients who do not see any reasons to change their behaviour, but rather explore why.

- $\quad$ Strengthen clients’ belief in their ability and possibilities for change.

In sum, the role of the professional is to help the client to formulate their own understanding of the problem, their own arguments for change, and to strengthen their decision and commitment to carry through with the changes.

In a motivational interview professionals are assigned to encourage clients to identify their problems and suggest solutions. However, clients do not act in a void, but are rather part of a wider discourse of what is normal and abnormal. In order to become healthy, clients are expected to acknowledge their problems. If this is not done, they will be positioned as deviant and abnormal, i.e. not healthy. Thus, the relationship could be described as self-governing, or rather, we could see this relationship as confessional (see Fejes \& Dahlstedt 2014), in that patients make confessions about their lifestyles and behaviour to a confessor, i.e. the health professional. In the confessional relation (see Fejes \& Dahlstedt 2014; Foucault 1998), clients are expected to direct their gaze inwards to their faults, temptations and deficits and disclose these to the confessor. A response from the confessor is not needed. Rather, the very act of disclosure is in itself shaped within wider discourses and is expressed in relation to a norm of good behaviour.

\section{Physical activity on prescription}

Physical activity on prescription is another technique that is described in the analysed texts and is aimed at the behavioural modification of clients.

Physical activity on prescription [...] is a concrete tool with which health care and external actors can promote physical activity in the population. At the same time it represents a working method that contributes to the goal that healthcare will conduct more disease preventive and health promotive work. (Institute of Public Health 2007, 12)

Physical activity is promoted as a way of making people more active, which in turn is expected to have positive effects on their health. Compared to motivational interviews, the client is expected to follow the advice of an expert. Based on an individual assessment by the expert, 
i.e. the health professional, the client can be offered a suitable physical programme. The textbook on physical activity on prescription published by the Public Health Agency of Sweden (2012, 15) states that:

\begin{abstract}
When offered physical activity on prescription, it is important to look at the medical history of the client, conduct a risk assessment and assess the motivation of the client, as well as what kind of support the client needs in order to increase his or her physical activity. It is also important that the advice is individual, that encouragement is provided, and that an agreement is made with the client about how to implement the prescription and when to follow up. It is also important that the level of exercise is reasonable in order to avoid failure and in order to increase adherence. It is appropriate to end the individual centred conversation by writing down the prescription, which can be regarded as an agreement.
\end{abstract}

Here, physical activity on prescription is constructed as a relational technique. An expert assesses clients based on their previous medical history and in dialogue with them. Further, the outcome of such a conversation is expected to result in a formal document, i.e. the prescription, which will be followed up at a later stage. Thus, clients are given advice as to how to improve their health. At the same time, clients know that the health professional will follow this up at a later stage (i.e. at a later meeting). As a client, there is an expectation to follow the advice in order to become shaped as a healthy and normal citizen.

Physical activity on prescription is in some ways similar to motivational interviews. Firstly, both techniques direct attention towards individuals with the aim of encouraging and motivating them to become healthier and 'normal'. Secondly, both techniques are relational, in that experts and clients are mutually expected to exchange knowledge about who the latter is and should become. Thirdly, such knowledge is in both instances based on science and 'scientific truth', as illustrated in the following quotation:

Motivational interviews aim to increase motivation among individuals in order to modify behaviour. Today, there is evidence that different forms of short advice and motivational interviews aimed at preventing alcohol abuse are effective. Such effects have also been confirmed regarding physical activity on prescription. (Ministry of Health and Social Affairs 2007, 95)

Through the mobilisation of scientific knowledge and the assessment nature of both techniques, technologies of power are at play. Through surveillance and by measuring clients' characters and health characteristics in relation to the norm (scientific knowledge production), the normal and abnormal client emerges.

However, technologies of power intersect with technologies of the self in the mobilisation of both techniques, albeit differently. In motivational interviews, the relation is confessional, in that clients direct their gaze inwards to their faults, temptations and behaviour, with the expectation that these will be disclosed to the confessor. The confessor, i.e. a health professional, is not positioned as an expert but rather as an elicitor of a client's own will to become healthy. Here, clients are shaped as experts about themselves. In the mobilisation of the technique of physical activity on prescription, the confessional relation is not as prominent, although it could become more apparent in the follow up meetings. The role of the health professional is one of an expert who judges what is normal or not, which is then disclosed to 
the client in terms of formal advice, i.e. prescription, to be followed. Thus, the prescription can be seen as a disciplinary technique that creates structure and encourages 'good habits'. In sum, the techniques of motivational interviews and physical activity on prescription both work towards the same goal, i.e. the shaping of a healthy citizen, although they operate in slightly different ways.

\section{Discussion}

In the last couple of decades education has become more strongly interlinked with learning and health. Although the general health of the population in Sweden is regarded as good, it has become a target for educational intervention. One of the main problems raised has been the increasing gap between those with good health and those with ill health. The gap is explained in terms of employment/unemployment, high/low levels of education, and a sense of responsibility for one's own health. According to the texts, citizens' educational achievements and levels of knowledge are construed as important. With low levels of knowledge and education, citizens may not know what kinds of life choices to make (what to eat, how to be active etc.) to become healthy, at the same time as they might make the wrong choices. Thus, a range of educational interventions are needed in order to correct those who do not or can nor take care of their own health.

Our analysis has shown how a self-governing citizen emerges by means of the techniques of motivational interviews and physical activity on prescription. By encouraging clients to confess their own faults and temptations to a confessor (health professional), it is expected that they will be in a position to see and solve their own problems. Although this latter technique is expert based, in that a professional provides more direct advice based on their assessment, the idea is that the client should take responsibility to engage in the prescribed activities. Technologies of power and the self thus intersect in both these techniques, and through them self-governing citizens emerge.

The self-governing citizen is shaped in what Rose (1999) calls an advanced liberal society and what Foucault calls a neoliberal governmentality (Foucault 2007). Here, the freedom of the individual is both the starting point for and the effect of governing. In other words, citizens are invited to reflect on themselves and their problems. Professionals may provide advice and support, but in the end it is the citizens themselves who will need to choose to become active, i.e. they will need to make choices about how to act (whether or not this is considered to be in accordance with current norms of good behaviour). Thus, motivational interviews and physical activity on prescription facilitate a choice (i.e. draw on clients' freedom). When this choice has been made, citizens then become free, i.e. they have shaped themselves as free choosing individuals. With a governmentality like this there is little need for direct governing i.e. governing by the state through law making or oppressive interventions. Rather, governing takes place at a distance (see Rose 1999), with each citizen becoming her or his own governor. Thus, the accountability for decisions shifts from the state to the individual. Citizens thereby become responsible for their own choices, successes or failures, while the state becomes an enabler (Fejes 2010; Rose 1999). 
Our analysis has provided a different kind of knowledge and normativity than the more normative accounts of how to find ways of improving the health of the population (see Hahn \& Truman 2015; Hammond 2002, 2004; Loucks et al. 2011). Instead of making claims about whether health interventions are good or bad, we have focused on illustrating how such interventions are dangerous as they contribute to the shaping of citizens in certain ways. The analysis thus raises serious questions by pointing to how new forms of power emerge that can incite, induce and seduce us into becoming something specific. By appealing to our own freedom of choice, and thus inviting us to shape ourselves as free, power becomes less visible and, in a way, dangerous (cf. Foucault 1983). What is at stake here is thus not so much our health, but rather who we are. As Foucault argues:

Maybe the problem of the self is not to discover what it is in its positivity; maybe the problem
is not to discover a positive self of the positive foundation for the self. Maybe our problem
now is to discover that the self is nothing else than the historical correlation of the technology
built in our history. Maybe the problem is to change those technologies (or maybe to get rid of
those technologies, and then, to get rid of the sacrifice which is linked to those technologies),
and in this case, one of the main political problems nowadays would be, in the strict sense of
the word, the politics of ourselves. (1997, 230-231)

Thus, rather than asking questions about the truth about ourselves (who we are as healthy citizens), we should perhaps be asking ourselves whether we really want to be governed in the ways outlined above? Asking different kinds of questions might provide opportunities to live the present otherwise (Foucault 1979; Fejes \& Dahlstedt 2014), or as Rose so aptly puts it, 'each person's life should be its own telos. It would thus have its own minimal normativity: we should oppose all that which stands in the way of life being its own telos' (Rose 1999, 283).

\section{References}

Berglund, G. (2008). On lifelong learning as stories of the present. Dissertation. Pedagogiska institutionen. Umeå universitet

Björklund, E. (2008). Constituting the Healthy Employee? Governing gendered subjects in workplace health promotion. Dissertation. Pedagogiska Institutionen. Umeå universitet

Dean, M. (1999). Governmentality: Power and rule in modern society. London: Sage publications

Ericsson, I. \& Karlsson, M. K. (2014). Motor skills and school performance in children with daily physical education in school - a 9-year intervention study. Scandinavian Journal of Medicine and Science in Sports. Vol 24, No 2, p. 273-278

Fejes, A (2006) The planetspeak discourse of lifelong learning in Sweden: What is an educable adult? Journal of Education policy, Vol 21, No 6, p. 697-716.

Fejes, A. (2010). Discourses on employability: constituting the responsible citizen. Studies in continuing education. Vol 32, No 2, p 89-102. 
Fejes, A. \& Dahlstedt, M. (2014) The confessing society: Foucault, confession and practices of lifelong learning. London. Routledge.

Fejes, A. \& Nicoll, K. (eds.) (2008) Foucault and Lifelong Learning. Governing the subject. New York. Routledge

Fejes, A. \& Nicoll, K. (eds.) (2015) Foucault and a politics of confession in education. London: Routledge.

Foucault, M. (1972). The archaeology of knowledge. London: Routledge

Foucault, M. (1978). The history of sexuality Volume 1: An Introduction. New York: Pantheon Books.

Foucault, M (1979) Vivre autrement le temps. In: Defert D, Ewald F and Lagrange J (eds) Dits et écrits III 1976-1979. Paris: Gallimard, pp. 788-790.

Foucault, M. (1980). Prison talk. In C. Gordon, (eds.). Power/Knowledge. Selected interviews \& other writings 1972-1977. New York: Pantheon

Foucault, M. (1983). On the genealogy of ethics: An overview of work in progress. In H.L, Dreyfus, and P. Rabinow, (eds). Michel Foucault: Beyond Structuralism and Hermeneutics. Chicago: The University of Chicago Press

Foucault, M. (1997). The politics of truth. Los Angeles: Semiotext(e).

Foucault, M. (1998). The will to knowledge: The History of sexuality 1. London: Penguin Books.

Foucault, M. (2003). Technologies of the self. In P. Rabinow \& N. Rose. (eds.). The Essential Works of Foucault: selections from the essential works of Foucault 1954 - 1984. New York: The New Press.

Foucault, M. (2007). Security, territory, population: Lectures at the Collège de France 19771978. Houndmills: Palgrave MacMillan.

Groot, W \& Maassen van der Brink, H. (2007). The health effects of education. Economics of Education Review Vol 26, p. 186-200

Hahn, R. A., \& Truman, B. I. (2015). Education Improves Public Health and Promotes Health Equity. International Journal of Health Services. Vol. 45, No 4, p. 657-678

Hammond, C. (2002). What is it about education that makes us healthy? Exploring education - health connection. International Journal of Lifelong Education. Vol 21, No 6, p 551-571

Hammond, C. (2004). Impacts of lifelong learning upon emotional resilience, psychological and mental health: fieldwork evidence. Oxford Review of Education. Vol 30, No 4, p 551-568 
Hills. A. P., Dengel, D. R. \& Lubans, D. R. (2015). Supporting Public Health Priorities: Recommendations for Physical Education and Physical Activity Promotion in Schools. Progress in cardiovascular diseases. Vol 57, No 4. p. 368- 374

Institute of Public Health, (2007). 2007:01. Fysisk aktivitet på recept - en vägledning för implementering. [Physical activity on prescription - a guide for implementation]. Stockholm

Loucks, E. B., Abrahamowicz, M., Xiao, Y. \& Lynch, J. W. (2011). Associations of education with 30 year life course blood pressure trajectories: Framingham Offspring Study. BMC Public Health. Vol 11, p 139.

Mayfield-Johnson, S., Rachal, J. R. \& Butler III, J. (2014).”When we learn better, we do better": Describing changes in empowerment through photovoice among community health advisors in a breast and cervical cancer health promotion program in Mississippi and Alabama. Adult Education Quarterly. Vol 63, no 2, p 91-109.

Merriam, S., B. \& Kee, Y. (2014). Promoting Community Wellbeing: The Case for Lifelong Learning for Older Adults. Adult Education Quarterly. Vol 63, no 2, p 128-144.

Motion to the Swedish Parliament. 2010/11:Ub445. Det livslånga lärandet och högre utbildning.[Lifelong learning and higher education] Stockholm

Ministry of Education (1999) 1999:141. Från Kunskapslyftet till en strategi för livslångt lärande [From the adult education initiative to a strategy for lifelong learning]. Stockholm: Ministry of Education.

Ministry of Education (2001). 2001/02:15. Den öppna högskolan. [The Open University] Stockholm: Ministry of Education.

Ministry of Health and Social Affairs. (2007). 2007/08:110 En förnyad folkhälsopolitik. [A renewed public health policy] Stockholm: Ministry of Health and Social Affairs.

Ministry of Health and Social Affairs. (2016) SOU 2016:55 Det handlar om jämlik hälsa. Utgångspunkter för kommissionens vidare arbete. [It's about equal health. The starting point for the commission's further work] Stockholm: Ministry of Health and Social Affairs.

National Board of Health and Welfare. (2016) Motiverande samtal. [Motivational interviews]. Accessed February 1, 2016.

http://www.socialstyrelsen.se/evidensbaseradpraktik/sokimetodguidenforsocialtarbete/motiver andesamtal

Nicoll, K., Fejes, A., Olson, M., Dahlstedt, M. \& Biesta, G. (2013). Opening discourses of citizenship education: a theorization with Foucault. Journal of Education Policy. Vol 28, No 6, p 828-846.

OECD. (1998). Human capital investment: An international comparison. Paris: Centre for Educational Research and Innovation, OECD. 
Olson, M., Fejes, A., Dahlstedt, M. \& Nicoll, K. (2014). Citizenship discourses: Production and curriculum. British Journal of Sociology of Education. Vol 36, No 7, p. 1036-1053

Olsson, U. (1997). Folkhälsa som pedagogiskt projekt: Bilden av hälsoupplysning i statens offentliga utredningar. [Public health as an educational project: the conception of health in governmental committees from the 1930th to the 1990th] Dissertation. Uppsala universitet

Popkewitz, T. S., Olsson, U. \& Peterson, K. (2006). The Learning Society, the Unfinished Cosmopolitan, and Governing Education, Public Health and Crime Prevention at the Beginning of the Twenty-First Century. Educational Philosophy and Theory. Vol 38, No 4, p 431-449

The Public Health Agency of Sweden. (2012) FaR. Individanpassad skriftlig ordination av fysisk aktivitet. [Physical activity on prescription. Individualized written prescription on physical activity]. Stockholm: Folkhälsomyndigheten

The Public Health Agency of Sweden. (2014). Folkhälsorapport. Folkhälsan i Sverige. [Public health in Sweden]. Stockholm

The Public Health Agency of Sweden. (2015a). Hälsa 2020. Ett policyramverk för sektorsövergripande insatser för hälsa och välbefinnande i WHO:s Europaregion [A policy framework for intersectoral action for health and well-being in the WHO European Region] Folkhälsomyndigheten

The Public Health Agency of Sweden. (2015b). Utbildningsnivå och hälsa - hur hänger de ihop? [Level of education and health - how are they connected?] Östersund:

Folkhälsomyndigheten

The Public Health Agency of Sweden, (2016). Public Health in Sweden 2016.

Accessed February 6, 2017, https://www.folkhalsomyndigheten.se/amnesomraden/livsvillkoroch-levnadsvanor/folkhalsans-utveckling-malomraden/ekonomiska-och-socialaforutsattningar/utbildningsniva/

Quennerstedt, M. (2006). Att lära sig hälsa. [Learning Health] Dissertation. Örebro universitet

Quennerstedt, M. (2008). Exploring the relation between physical activity and health - a salutogenic approach to physical education. Sport, Education and Society. Vol. 13, No. 3, p. 267-283

Rose, N. (1999) Powers of Freedom: reframing political thought. Cambridge: Cambridge SCB.se [Statistics Sweden]

Accessed February 6, 2017, http://www.scb.se/sv_/Hitta-statistik/Artiklar/Lang-utbildningforlanger-livet/

Simons, M. \& Masschelein, J. (2008). The Governmentalization of Learning and the Assemblage of a Learning Apparatus. Educational Theory. Vol 58, No 4, p 391-415 
Tolgfors, B \& Öhman, M. (2016). The implications of assessment for learning in physical education and health. European Physical Education Review. Vol. 22, No 2, p 150-166

Zepke, N. (2013). Lifelong education for subjective well-being: how do engagement and active citizenship contribute? International Journal of Lifelong Education. Vol 32, No 5, p 639-651 